\title{
FIRST DESCRIPTION OF ANTIBACTERIAL AND IN VITRO WOUND HEALING PROPERTIES OF COCOS NUCIFERA TOMENTUM
}

\author{
HARITHA KH ${ }^{1}$, SUJITHA KUTTINATH ${ }^{1}$, RAM RAMMOHAN ${ }^{2 *}$
}

${ }^{1}$ Department of Microbiology, Nehru Arts and Science College, Coimbatore, Tamil Nadu, India. ${ }^{2}$ Division of Laboratory Services, Aravind Eye Hospital and Postgraduate Institute of Ophthalmology, Coimbatore, Tamil Nadu, India. Email: ramrammohan2004@yahoo.com

Received: 07 January 2019, Revised and Accepted: 26 March 2019

\section{ABSTRACT}

Objective: The objective of the study was to evaluate the antibacterial, antioxidant, and in vitro wound healing property of Cocos nucifera tomentum.

Methods: Ethanolic and methanolic extracts of $C$. nucifera tomentum were prepared using the Soxhlet extraction method and aqueous extract was prepared by the shaker flask method. These extracts were investigated for the phytochemical profile by gas chromatography and mass spectroscopy (GC-MS) and liquid chromatography-quadrupole-time-of-flight mass spectrometry (LC-Q-ToF MS), for antibacterial activity by microdilution method, for the antioxidant property by 2,2-diphenyl-1-picrylhydrazyl assay, and for in vitro wound healing activity on cell lines.

Results: The preliminary phytochemical screening showed the presence of alkaloids, flavonoids, and various bioactive components. GC-MS and LCQ-ToF MS analysis of extracts revealed the presence of bioactive compounds known to have wound healing properties as well as antioxidant and antimicrobial activities. The methanolic extract had better antibacterial activity against Proteus vulgaris and Escherichia coli, and better antioxidant and wound healing activity, when compared to the ethanolic and aqueous extracts.

Conclusion: The present study suggests that $C$. nucifera tomentum might be a potential therapeutic source for topical antibacterial and wound healing applications.

Keywords: Cocos nucifera, Tomentum, Antioxidant, Antibacterial, Wound healing.

(c) 2019 The Authors. Published by Innovare Academic Sciences Pvt Ltd. This is an open access article under the CC BY license (http://creativecommons. org/licenses/by/4. 0/) DOI: http://dx.doi.org/10.22159/ajpcr.2019.v12i5.31295

\section{INTRODUCTION}

Wounds are breaks in the skin (due to cuts, scrapes, or scratches) or injuries in other body tissues. They often happen due to trauma or due to an accident, but can also be caused due to surgery, or by sutures and stitches. A major problem with wounds is the risk of infections caused by microorganisms. Inhibition or killing of microorganisms is an essential component of the wound healing process and is generally achieved with antimicrobial agents (antibiotics). These can be applied to the wound (topical) or be given systemically (e.g., by oral administration) [1,2].

Cocos nucifera L., commonly known as the Coconut, is a member of the family Arecaceae (Palms). It is highly valued both as a source of food and a source of medicines. The plant is said to have originated from Southeast Asia, or Islands of the Indian and Pacific oceans [3]. India is the third largest coconut producing country [4]. Only recently has modern medical science unlocked the secrets to coconut's amazing healing powers. It is widely used in Ayurveda for various skin problems and microbial infections [5]. Coconut shell charcoal powder is also very effective as a potential medicine for wound healing, for kidney trouble, for ulcers, and other soft tissue diseases [6]. Virgin coconut oil extract contains various phytochemicals and shows high antioxidant activity [7]. The $C$. nucifera $L$. leaf petiole possesses a caducous tomentum abaxially, which appears as a closely matted hair or downy covering. The villagers and farmers of Kerala and Tamil Nadu in India, traditionally apply the tomentum of coconut on cuts and wounds. Such ethnomedicines are widely prevalent and they have been the source for the development of new drugs $[8,9]$.

A survey of literature reveals that so far, no studies have been carried out on the antibacterial activity, antioxidant properties, or wound-healing effects of $C$. nucifera tomentum and/or its extracts. Thus, the objectives of our present study were to identify and compare the phytochemical constituents, antioxidant activity, antibacterial properties, and in vitro wound healing activity of $C$. nucifera tomentum extracts.

\section{MATERIALS AND METHODS}

\section{Collection of plant materials}

Fresh C. nucifera tomentum was collected from Coconut Research Station, Tamil Nadu Agricultural University (Aliyar, Tamil Nadu, India). The tomentum was collected from 4 to 5 -year-old coconut trees and was identified and authenticated as C. nucifera $L$. belonging to family Arecaceae, at the Institute of Forest Genetics and Tree Breeding, Coimbatore, Tamil Nadu, India. The herbarium was created and the specimen of leaves with tomentum was deposited at the Institute of Forest Genetics and Tree Breeding, Coimbatore, Tamil Nadu, India.

\section{Extraction of plant material}

About $50 \mathrm{~g}$ of the dried tomentum was continuously extracted with $100 \%$ methanol (TM) or $100 \%$ ethanol (TE) using Soxhlet apparatus at $60^{\circ} \mathrm{C}$ up to $12 \mathrm{~h}[10,11]$, while aqueous (TA) extraction was carried out by the shaker flask method [12]. The extracts were filtered and concentrated in a rotary evaporator at $35^{\circ} \mathrm{C}-45^{\circ} \mathrm{C}$ under reduced pressure, to obtain the crude extract. The crude extract was stored in an air-tight container at $4^{\circ} \mathrm{C}$ and used for further studies.

\section{Preliminary phytochemical screening}

The freshly prepared ethanolic, methanolic, and aqueous extracts of C. nucifera tomentum were subjected to qualitative chemical tests (Mayer's test, Dragendorff's test, and Wagner's test). Phenols, flavonoids, tannins, terpenoids, and sterols were assayed by standard methods [13].

Gas chromatography-mass spectroscopy (GC-MS) analysis GC-MS is used for identification and quantitation of volatile and organic compounds in complex mixtures and for the determination 
of molecular and elemental compositions of unknown organic compounds in a mixture [14]. GC-MS analysis for TE and TM was carried out on the Shimadzu GC-MS (QP2010S). The column used was Rxi-5sil MS ( $300 \mathrm{~mm} \times 0.2 \mathrm{~mm} \times 0.25 \mu \mathrm{m}$ ). Helium was the carrier gas at a flow rate of $1.0 \mathrm{~mL} / \mathrm{min}$. The instrument was set to an initial temperature of $80^{\circ} \mathrm{C}$ and maintained for $2 \mathrm{~min}$. At the end of this period, the oven temperature was raised to $280^{\circ} \mathrm{C}$ (at $5^{\circ} \mathrm{C} / \mathrm{min}$ ) and maintained for $5 \mathrm{~min}$. Injection port temperature was $260^{\circ} \mathrm{C}$, the injection volume was $1.0 \mu \mathrm{L}$, and the helium flow rate was $3.0 \mathrm{~mL} / \mathrm{min}$. The total GC-MS running time was $40.8 \mathrm{~min}$. The phytochemical constituents were identified using the National Institute of Standards and Technology Mass Spectral Database (NIST 11) and WILEY 8 library $[15,16]$.

Liquid chromatography-quadrupole-time-of-flight mass spectrometry (LC-Q-ToF MS) analysis

LC-Q-ToF MS is used to determine the fragmentation and structural information of the known and unknown compounds present in a complex mixture [17]. LC-Q-TOF MS analysis for TA was performed on the Acquity $\mathrm{H}$ class (Waters India Pvt. Ltd., Bengaluru, India) ultraperformance LC system connected with Xevo G2 (Waters India Pvt. Ltd., Bengaluru, India) Q-TOF mass spectrometer with LC column BEH C18 column $(50 \mathrm{~mm} \times 2.1 \mathrm{~mm} \times 1.7 \mu \mathrm{m})$. The mobile phase was a gradient of water $+0.1 \%$ formic acid (A), and methanol (B), and the samples were analyzed from $0.1 \mathrm{~min}$ to $9.0 \mathrm{~min}$. The flow rate was $0.3 \mathrm{~mL} / \mathrm{min}$. Total run time was $9 \mathrm{~min}$. The LC-Q-TOF mass spectrometer analysis was performed with $135^{\circ} \mathrm{C}$ source temperature and $350^{\circ} \mathrm{C}$ desolvation temperature. The positive ionization mode was with the energy of $3 \mathrm{kV}$, with sample cone at $30 \mathrm{~V}$ and extraction cone at $1 \mathrm{~V}$, while the negative ionization mode was with the capillary voltage at $2.5 \mathrm{kV}$, and sample cone at $30 \mathrm{~V}$, and extraction cone at $1 \mathrm{~V}$. The identification of compounds present in the sample was performed by comparison of MS/MS Spectra using the ChemSpider database [18].

\section{Antibacterial activity by microdilution assay}

The minimum inhibitory concentrations (MIC) of the extracts against test bacteria were determined using a modified microdilution technique originally described by Eloff [19]. Test solutions $(10 \mathrm{mg} / \mathrm{mL})$ of the extracts were prepared with Dimethyl sulfoxide and serial two-fold dilutions were made. $50 \mu \mathrm{L}$ of the test bacteria $\left(1.0 \times 10^{7} \mathrm{CFU} / \mathrm{mL}\right)$ were grown in tryptone soya broth. The covered microplates were incubated at $37^{\circ} \mathrm{C}$ for $24 \mathrm{~h} \mathrm{[20]}$. To indicate bacterial growth $30 \mu \mathrm{L}$ of thiazolyl blue tetrazolium bromide dye was added to each well, and plates were further incubated for $30 \mathrm{~min}$ at $37^{\circ} \mathrm{C}$. Formation of blue color indicated the presence of viable cells [21]. The experiments were carried out in triplicate.

\section{Antioxidant activity}

The antioxidant activity of the tomentum extracts was determined in terms of hydrogen donating or radical scavenging ability using the stable radical 2,2-diphenyl-1-picrylhydrazyl (DPPH) assay [22]. Samples and standard (ascorbic acid) were taken in various concentrations, and the volume was adjusted to $100 \mu \mathrm{L}$ with methanol. About $3 \mathrm{~mL}$ of $0.1 \mathrm{mM}$ methanolic solution of DPPH was added to the aliquots of samples and mixed well. Negative control was prepared by adding $100 \mu \mathrm{L}$ of methanol in $3 \mathrm{~mL}$ of $0.1 \mathrm{mM}$ methanolic solution of DPPH. The tubes were allowed to stand in the dark for $30 \mathrm{~min}$ at room temperature. The absorbance of the sample was measured at $517 \mathrm{~nm}$ against a Blank [23]. The radical scavenging activity was calculated using the following formula [24]:

\section{DPPH scavenging activity $\%=[($ Control-Test sample $) /$ Control $] * 100$}

\section{Scratch wound healing assay}

Mouse fibroblast cells (L929) were grown in 24-well plates at a density of $1 \times 10^{5}$ cells $/ \mathrm{mL}$ and cultured to $80 \%$ confluency. A small linear scratch was created in the confluent monolayer by gently scraping with a sterile cell scrapper [25]. Cells were thoroughly rinsed with phosphate-buffered saline to remove cellular debris and treated with different concentrations of the methanolic or ethanolic extracts of C. nucifera tomentum. Cell proliferation was monitored at different time points ( $0 \mathrm{~h}, 4 \mathrm{~h}, 18 \mathrm{~h}$, and $24 \mathrm{~h})$, and images of migrated cells were taken at different time points using a digital camera (Nikon, Tokyo, Japan) connected to an inverted phase contrast microscope (Radical Instruments, India)

\section{RESULTS}

Preliminary phytochemical screening

The phytochemical analysis of the tomentum of $C$. nucifera $L$. showed the presence of alkaloids in TE and TM, while it was absent in TA. Tannins, phenols, flavonoids, and sterols were present in varying concentrations in all extracts, as indicated by the intensity of the colored solution and precipitates. Terpenoids were absent in TE and TA but present in TM (Table 1).

\section{GC-MS analysis}

GC-MS was carried out to identify the bioactive compounds having long chain hydrocarbons, esters, acids, phenolic compounds, etc. In the present study, more than 15 bioactive compounds were identified in TM and TE. The major constituents of TM are 1-Dodecanol (RT-16.46), Dodecanoic acid methyl ester (RT-17.62), 1- Tetradecanol (RT-21.23) along with some other minor compounds which is proven to have pharmacological activities (Fig. 1). These identified compounds are known to possess antibacterial, anti-inflammatory, anticancer, antifungal, antioxidant, cancer preventive, nematicidal, or hypercholesterolemic properties $[12,26,27]$. The major constituents of TE were 1,2-benzenedicarboxylic acid, bis (2-methyl propyl) ester (RT-16.19), E-15-heptadecenal (RT14.94), and stigmasterol (RT-37.20), all of which have been previously reported to possess antimicrobial and antifouling properties, antimalarial, antioxidant, hypoglycemic, thyroid inhibiting, anticancer, antiarthritic, or anti-inflammatory activities (Fig. 2) [28-34].

\section{LC-Q-ToF MS analysis}

The total ion chromatogram of TA is represented in Figs. 3 and 4. Although several bioactive compounds have been identified, further studies are needed to get complete profiling of components present in the sample $[35,36]$.

Table 1: Phytochemical profile of Cocos nucifera tomentum extracts

\begin{tabular}{lllll}
\hline S. No. & Name of compounds & TE & TM & TA \\
\hline 1 & Alkaloids & & & \\
& a. Mayer's test & + & ++ & - \\
& b. Dragendorff's test & ++ & +++ & - \\
& c. Wagner's test & + & ++ & - \\
2 & Phenols & + & ++ & + \\
3 & Flavonoids & ++ & ++ & + \\
4 & Tannins & + & +++ & ++ \\
5 & Terpenoids & - & + & - \\
6 & Sterols & + & + & + \\
\hline
\end{tabular}

+++: High, ++: Moderately present, +: Weakly present, -: Absent

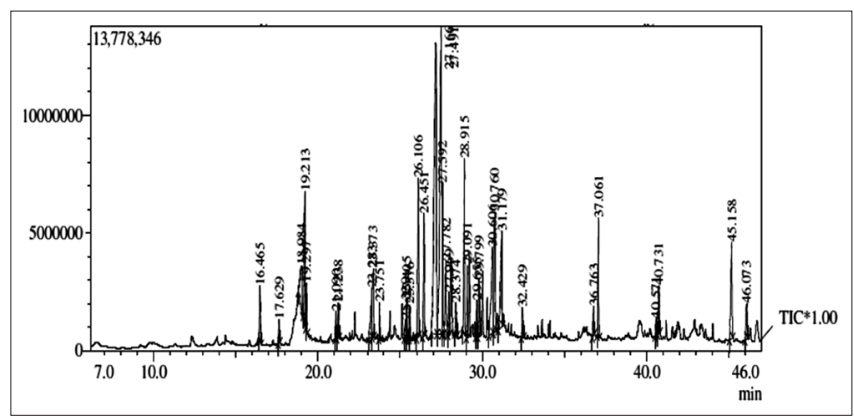

Fig. 1: Gas chromatography and mass spectroscopy chromatogram of TM 


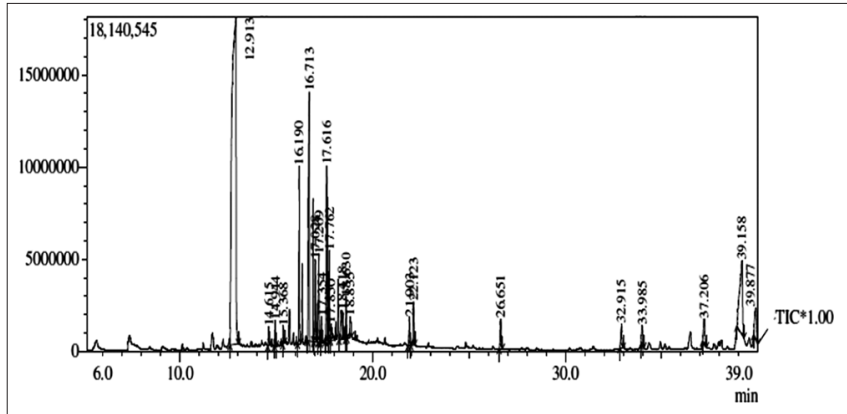

Fig. 2: Gas chromatography and mass spectroscopy chromatogram of TE

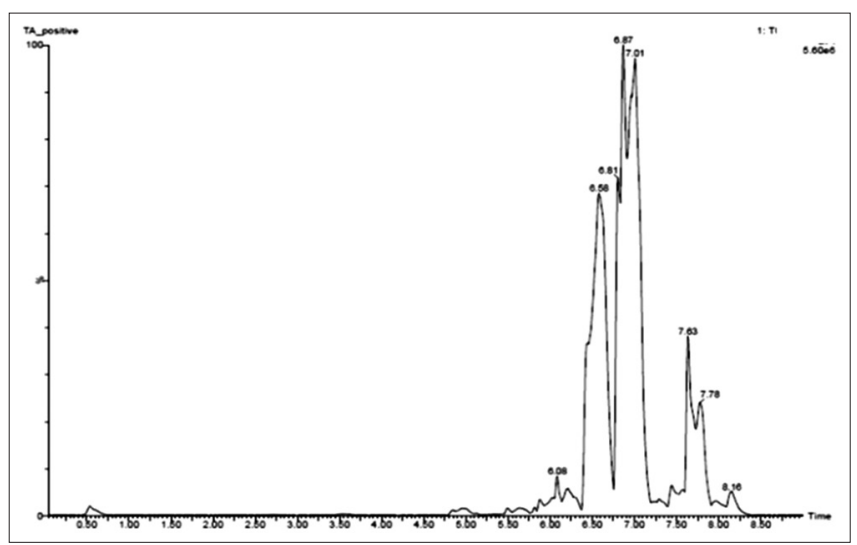

Fig. 3: Liquid chromatography-quadrupole-time-of-flight mass spectrometry chromatographic profiles of TA (positive ion mode)

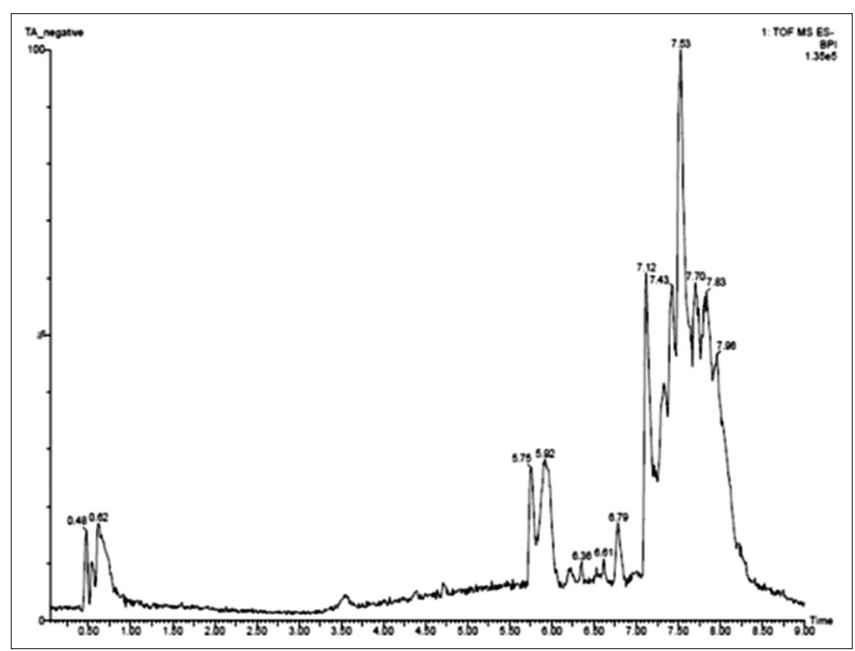

Fig. 4: Liquid chromatography-quadrupole-time-of-flight mass spectrometry chromatographic profiles of TA (negative ion mode)

\section{The MIC of tomentum extracts}

The MIC - determined as the lowest concentration of the crude extract that showed no microbial growth - was carried out against three Gram-negative and one Gram-positive bacteria using various extracts of $C$. nucifera (Table 2). The MIC of TM extract against Escherichia coli was $2.5 \mathrm{mg} / \mathrm{mL}$, while the MICs for TE and TA were $5 \mathrm{mg} / \mathrm{mL}$. In the case of Pseudomonas aeruginosa, all the three extracts showed similar MICs $(2.5 \mathrm{mg} / \mathrm{mL})$. The MICs of gentamicin was not determined against E. coli and P. aeruginosa. The MIC value against Proteus vulgaris of TM was $1.25 \mathrm{mg} / \mathrm{mL}$, while the other two extracts showed a MIC of $2.5 \mathrm{mg} / \mathrm{mL}$. Against Staphylococcus aureus, TM and TA had the highest MIC of $5 \mathrm{mg} / \mathrm{mL}$, while for TE it was $10 \mathrm{mg} / \mathrm{mL}$. Chloramphenicol showed $0.625 \mathrm{mg} / \mathrm{mL}$ MIC against $P$. vulgaris and $S$. aureus. The different susceptibilities of the various organisms to different concentrations of extracts were noted. It was observed that $P$. vulgaris and $E$. coli were more sensitive to $\mathrm{TM}$

\section{Reference antibiotics}

Chloramphenicol for Gram-positive bacteria and gentamicin for Gramnegative bacteria were used.

\section{Antioxidant activity}

Comparison of the antioxidant activity of the tomentum extracts and ascorbic acid by DPPH method is shown in Fig. 5 . The various extracts $\mathrm{TM}, \mathrm{TE}$, and TA exhibited significant dose-dependent inhibition of DPPH activity. Among these, TM showed the highest potential to scavenge DPPH when compared to TE and TA. The reduction capability of DPPH radicals was determined by the decrease in its absorbance at $517 \mathrm{~nm}$ which is induced by antioxidants [37]. At $400 \mu \mathrm{g} / \mathrm{mL}$ concentration, the percentage of inhibition of TM, TE, and TA is $49 \%, 15.8 \%$, and $38 \%$, respectively, when compared to ascorbic acid as the standard (39\%). The $\mathrm{IC}_{50}$ value of TM was $400 \mu \mathrm{g} / \mathrm{mL}$, TA was $800 \mu \mathrm{g} / \mathrm{mL}$, and the TA was $1000 \mu \mathrm{g} / \mathrm{mL}$. In our study, the highest antioxidant activity was found in $\mathrm{TM}$, followed by TA and TE.

\section{Scratch assay}

Proper healing of wounds is necessary for the restoration of the skin [5]. For our in vitro wound-healing assay, the L929 mouse fibroblast cell line was used for the surrogate "Scratch assay." A small linear scratch was created in a confluent monolayer of L929 cells by scraping with a sterile cell scraper. An image analyzer was then used to calculate the time required to close the gap at different concentrations of extracts. The time taken to close the gap using various extracts was plotted and compared with untreated cells (Fig. 6). The results showed that at a concentration of $75 \mathrm{ug} / \mathrm{mL}$, TM closed the gap in the scratch at the $18^{\text {th }} \mathrm{h}$ when compared the TE, TA, and control (Fig. 7). In the present study, formulation of at the concentration of $50 \mu \mathrm{g} / \mathrm{mL}$ and $75 \mu \mathrm{g} / \mathrm{mL}$ of TM showed significant mobilization of L929 cells and closed the gap, when compared to the control without the addition of formulation. Photographs indicating comparative cell migration in normal control at the $0^{\text {th }} \mathrm{h}$, non-treated control, TM, TE, and TA at the $18^{\text {th }} \mathrm{h}$ time intervals.

\section{DISCUSSION}

C. nucifera is a well-known plant, and its parts (including the milk and oil) are used both as a food, as well as in herbal medicines [38]. Earlier studies have reported the antipyretic, wound healing activity, and anti-hypertensive effects of other parts of $C$. nucifera $[39,40]$.

Table 2: MICs of TM, TE, and TA extract of tomentum by microdilution method

\begin{tabular}{|c|c|c|c|c|}
\hline Extract/MIC (mg/mL) & $\begin{array}{l}\text { E. coli } \\
\text { ATCC } 25922\end{array}$ & $\begin{array}{l}\text { P. aeruginosa } \\
\text { ATCC } 27853\end{array}$ & $\begin{array}{l}\text { Proteus vulgaris } \\
\text { NCIM } 2027\end{array}$ & $\begin{array}{l}\text { S. aureus } \\
\text { ATCC } 25923\end{array}$ \\
\hline TM & 2.5 & 2.5 & 1.25 & 5 \\
\hline $\mathrm{TE}$ & 5 & 2.5 & 2.5 & 10 \\
\hline TA & 5 & 2.5 & 2.5 & 5 \\
\hline Reference antibiotic & $\mathrm{Nd}^{\mathrm{g}}$ & $\mathrm{Nd}^{\mathrm{g}}$ & $0.625^{g}$ & $0.625^{c}$ \\
\hline
\end{tabular}

Nd: Not determined, G: Gentamicin, C: Chloramphenicol, E. coli: Escherichia coli, P. aeruginosa: Pseudomonas aeruginosa, S. aureus: Staphylococcus aureus, MICs: Minimum inhibitory concentrations 


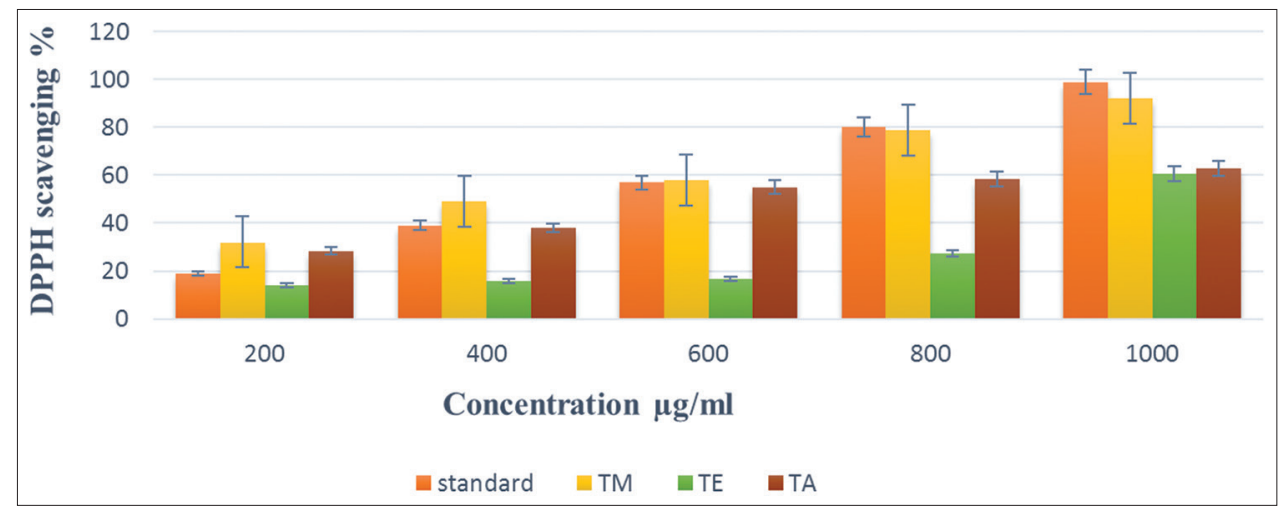

Fig. 5: 2,2-Diphenyl-1-picrylhydrazyl scavenging assay of tomentum extracts. The values are in mean $\pm S D(n=3)$

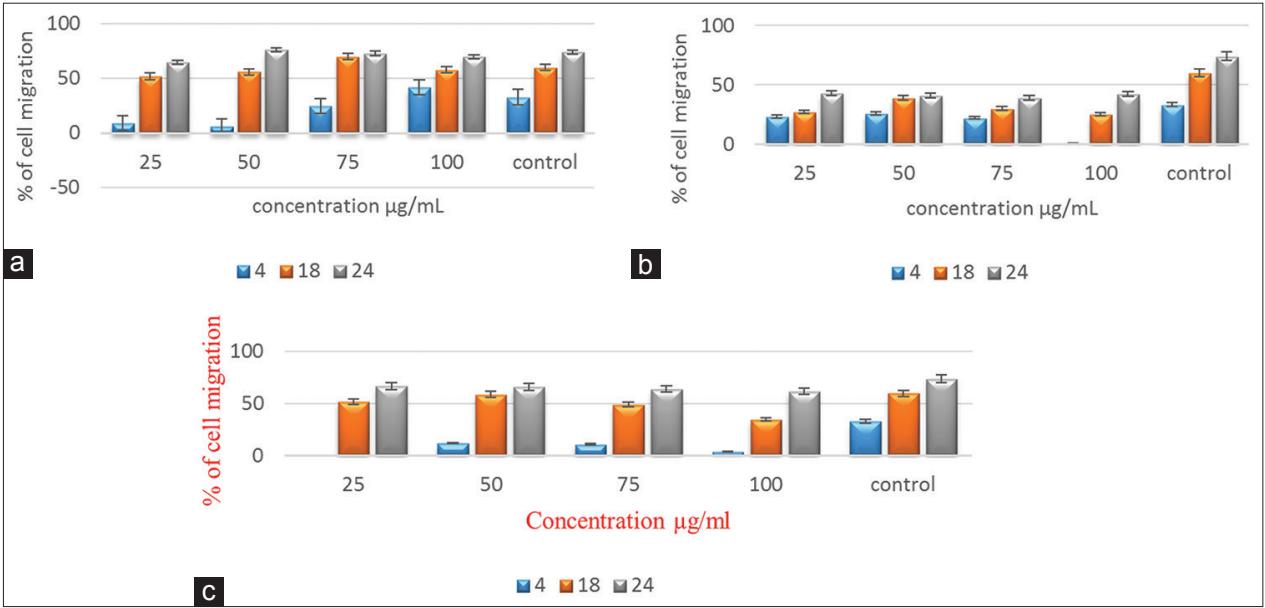

Fig. 6: (a-c) Cell migration percentage using L929 cell line (all the values were calculated as mean $\pm \mathrm{SD}$; $\mathrm{n}=3$ ) (a) $\mathrm{TM}$, (b) TE, (c) TA

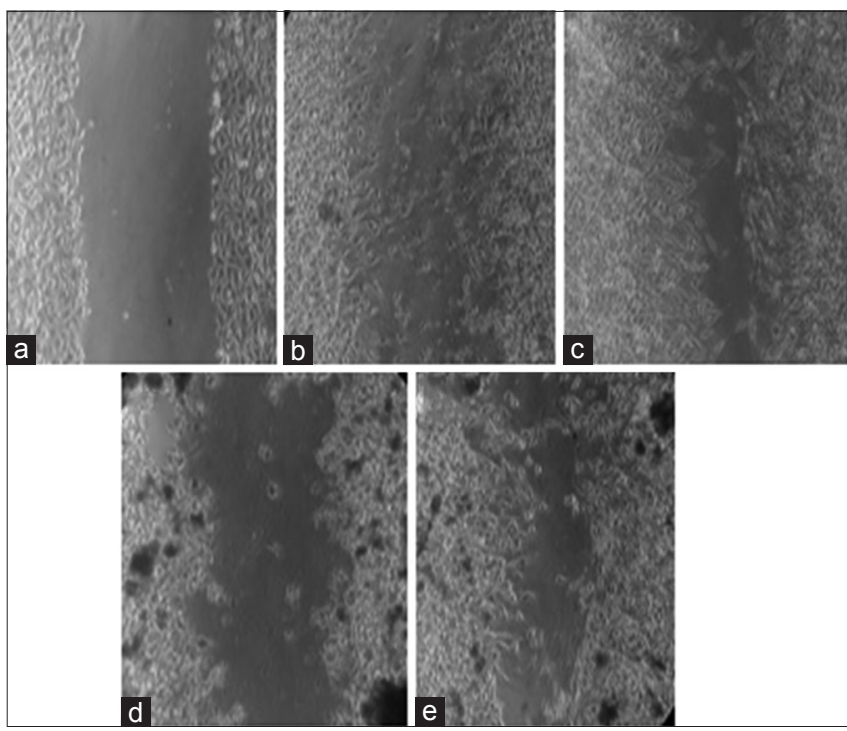

Fig. 7: (a) Normal control at $0^{\text {th }} h$, (b) control at $18^{\text {th }} h$, (c) TM at $18^{\text {th }} \mathrm{h}(75 \mu \mathrm{g} / \mathrm{ml})$, (d) TE at $18^{\text {th }} \mathrm{h}(75 \mu \mathrm{g} / \mathrm{ml})$, (e) TA at $18^{\text {th }} \mathrm{h}$ $(75 \mu \mathrm{g} / \mathrm{ml})$

The presence of phenolic compounds such as sterols and terpenoids contributes to the antioxidant properties of the tomentum [41]. GC-MS is the best technique to identify the bioactive constituents of long-chain hydrocarbons, alcohols, acids, esters, alkaloids, steroids, amino acid, and nitro compounds [33]. In the present study, all the compounds identified are known to possess biological activities. However, for the
LC-Q-ToF MS analysis, further studies are needed to obtain the complete profile of compounds.

Our MIC studies show that test organisms are more sensitive to methanolic extracts of the coconut tomentum and that this antibacterial activity could very well be due to the phytoconstituents present (such as the phenolic compounds) [42-44]. It has earlier been reported that C. nucifera oil with silver sulfadiazine is useful in treating burns and wounds [45]

However, our present study is the first to demonstrate the wound healing effect of the hitherto un-studied $C$. nucifera tomentum. The wound healing property of tomentum may be due to either a rapid cell proliferation stimulated by growth-promoting phytochemicals and antioxidants present, or by prevention of infection due to antimicrobial activity.

\section{CONCLUSION}

This work is the first report to identify compounds from the extracts of C.nucifera tomentum, through qualitative and quantitative phytochemical analyses. This study also tested the antioxidant, antibacterial, and in vitro wound healing activities of alcoholic and aqueous extracts of $C$. nucifera tomentum. The methanolic extract of the coconut tomentum has significant antimicrobial, antioxidant, and wound healing properties. This study reveals the potential source of useful drugs from C. nucifera tomentum.

\section{ACKNOWLEDGMENT}

The authors are thankful for the Head and Staff, Department of Microbiology, Nehru Arts and Science College, Coimbatore, India, for their encouragement to carry out this study. 


\section{AUTHORS' CONTRIBUTIONS}

Haritha KH: All fieldwork, laboratory experiments, and preparation of documents. Sujitha Kuttinath: Supporting laboratory experiments. Ram Rammohan: Guide, Experimental designs, troubleshooting, and preparation of the manuscript.

\section{CONFLICTS OF INTEREST}

The authors declare that they have no conflicts of interest.

\section{REFERENCES}

1. Bowler PG, Duerden BI, Armstrong DG. Wound microbiology and associated approaches to wound management. Clin Microbiol Rev 2001;14:244-69.

2. Kumar B, Vijayakumar M, Govindarajan R, Pushpangadan P. Ethnopharmacological approaches to wound healing - exploring medicinal plants of India. J Ethnopharmacol 2007;114:103-13.

3. Lima EB, Sousa CN, Meneses LN, Ximenes NC, Santos Júnior MA, Vasconcelos GS, et al. Cocos nucifera (L.) (Arecaceae): A phytochemical and pharmacological review. Braz J Med Biol Res 2015;48:953-64

4. DebMandal M, Mandal S. Coconut (Cocos nucifera L.: Arecaceae): In health promotion and disease prevention. Asian Pac J Trop Med 2011; 4:241-7.

5. Srivastava P, Durgaprasad S. Burn wound healing property of Cocos nucifera: An appraisal. Indian J Pharmacol 2008;40:144-6.

6. Loneza G, Odiem MM, Esther C. Powdered coconut shell charcoal: A potential alternative medicine for some identified ailments in soft tissues. An Interdisciplinary research. Int J Adv Res IT Eng 2013;2:61-9.

7. Zunairah A, Mohamad RS, Rosnani $\mathrm{H}$. Evaluation of wound closure activity of Cocos nucifera oil on scratched monolayer of human dermal fibroblasts. Chem Eng Trans 2017;56:1657-62.

8. Latheef AK, Smitha PK, Remashree AB. Ethnomedicine used for treating cuts and wounds by the tribes of Attappady, Kerala. Int J Herb Med 2014;2:1-8.

9. Thomas B, Arumugam R, Veerasamy A, Ramamoorthy S. Ethnomedicinal plants used for the treatment of cuts and wounds by Kuruma tribes, Wayanadu districts of Kerala, India. Asian Pac J Trop Biomed 2014:4:S488-91.

10. Devendran G, Ganesan S. Phytochemical analysis of leaf extract of plant Costus spicatus By GC-MS method. J Drug Deliv Ther 2015;5:24-6.

11. Jayaveera KN, Yoganandham Reddy K, Govindarajula Y, Kumanan R. Phytochemical screenings, antibacterial activity and physico chemical constants of ethanolic extract of Euphorbia thymifolia linn. Int J Pharm Pharm Sci 2010;3:81.

12. Handa SS, Khanuja SP, Longa G, Rakesh DD. Extraction Technologies for Medicinal and Aromatic Plants. Italy, United Nations: Industrial Development Organization and the International Centre for Science and High Technology; 2008.

13. Harbone JB. Phytochemical Methods. London: Chapman \& Hall; 1999. p. 60-6.

14. Lakshmi Hima Bindu MR, Parameswari AS, Gopinath C. A review on GC-MS and method development and validation. Int J Pharm Qual Assur 2013;4:42-51

15. National Institute of Standards and Technology. NIST Standard Reference Database 1A. NIST Mass Spectral Search Program Version 2.0g. Gaithersburg, MD: National Institute of Standards and Technology; 2011.

16. Willey/NIST. The Willey/NBS Registry of Mass Spectral Data. Mass Spectral Library version 2.0. $8^{\text {th }}$ ed. New York: J. Willey and Sons, Inc., NIST/EPA/NIH; 2005

17. Ferrer I, Thurman ME. Liquid Chromatography/time of flight/mass spectrometry $(\mathrm{LC} / \mathrm{TOF} / \mathrm{MS})$ for the analysis of emerging contaminants. Trends Anal Chem 2003;22:750-6.

18. Chemspider from Royal Society of Chemistry. Cambridge. Available from: http://www.chemspider.com. [Last accessed on 2018 Jun 20].

19. Eloff JN. A sensitive and quick microplate method to determine the minimal inhibitory concentration of plant extracts for bacteria. Planta Med 1998;64:711-3

20. Clinical and Laboratory Standards Institute. Performance Standards for Antimicrobial Disc Susceptibility Tests. Approved Standard CLSI Document. M100 S26. 27 $7^{\text {th }}$ ed. Clinical and Laboratory Standards Institute; 2017
21. Balouiri M, Sadiki M, Ibnsouda SK. Methods for in vitro evaluating antimicrobial activity: A review. J Pharm Anal 2016;6:71-9.

22. Braca A, De Tommasi N, Di Bari L, Pizza C, Politi M, Morelli I, et al. Antioxidant principles from Bauhinia tarapotensis. J Nat Prod 2001; 64:892-5.

23. Udaya Prakash NK, Bhuvaneswari S, Sripriya N, Prameela L, Bhagya R, Radhika B, et al. Antioxidant activity of common plants of Northern Tamil Nadu, India. Int J Pharm Pharm Sci 2014;6:128-32.

24. Shabrina R, Elya B, Noviani A. Anti-oxidant activities of fractions from ethyl acetate extracts of farcinia fruticosa lauterb leaves. Int J Appl Pharm 2018;10:44-50.

25. Liang CC, Park AY, Guan JL. In vitro scratch assay: A convenient and inexpensive method for analysis of cell migration in vitro. Nat Protoc 2007;2:329-33

26. Yogeswari S, Ramalakshmi S, Neelavathy R, Muthumary J. Identification and comparative studies of different volatile fractions from Monochaetia kansensis By GC-MS. Global J Pharm 2012;6:65-71.

27. Kalaivani KM, Jonnalgadda B, Arockiasamy S. GC-MS analysis of chloroform extract of Croton bonplandianum. Int J Pharm Bio Sci 2013; 4:613-7.

28. Sermakkan M, Thangapandian V. GC-MS analysis of Cassia Italic leaf methanol extract. Asian J Pharm Clin Res 2012;5:90-4.

29. Thomas E, Aneesh TP, Thomas DG, Anandhan R. GC-MS analysis of phytochemical compounds present in the rhizomes of Nervilia aragoana gaup. Asian J Pharm Clin Res 2013;6:68-74.

30. Dandekar R, Fegade B, Bhaskar VH. GC-MS analysis of phytochonstituents in alcohol extract of Epiphyllum oxypetalum leaves. J Pharmacogn Phytochem 2015;4:149-54.

31. Patel J, Reddy V, Kumar Satyara GS, Bajari B. Gas chromatography and mass spectroscopy analysis of bioactive components on the leaf extract of Terminalia coriacea: A potential folklore medicinal plant. Int J Green Pharm 2017;11:S140.

32. Parasuraman S, Raveendran R, MadhavRao C. GC-MS analysis of leaf extracts of Cleistanthus collinus roxb: Euphorbiaceae. Int J Pharm Sci 2009; $1: 284-6$

33. Jenecius A, Mohan VR. GC-MS analysis of bioactive compounds on the stem exatract of Bacolepsis nervosa decne. Ex.Moe (Periplocaceae). J Pharm Pharm Sci 2014;3:1044-59.

34. Duke JA. Duke's Phytochemical and Ethnobotanical Databases. 12.6 Beta. Vol. 9. Beltsville, Md.: ARS/USDA; 2018.

35. Pubchem from NCBI. Available from: http://www.pubchem.ncbi.nlm. nih.gov. [Last accessed on 2018 Jun 20].

36. Narendhirakannan RT, Jesuthankaraj GN, Caroline A, Lincy S, Saj M, Durai D. Evaluation of antibacterial, antioxidant and wound healing properties of seven traditional medicinal plants from India in experimental animals. Asian Pac J Trop Biomed 2012;2:s1245-53.

37. Durgaprasad B, Chandrakanth B, Babu R, Kumar PK, Sastry GV. Screening of wound healing activity of bark of Aleurites moluccana $\mathrm{L}$. Int J Pharm Res Anal 2011;1:21-5.

38. Alanís AD, Calzada F, Cervantes JA, Torres J, Ceballos GM. Antibacterial properties of some plants used in Mexican traditional medicine for the treatment of gastrointestinal disorders. J Ethnopharmacol 2005;100:153-7.

39. Alleyne T, Roache S, Thomas C, Shirley A. The control of hypertension by use of coconut water and Mauby: Two tropical food drinks. West Indian Med J 2005;54:3-8.

40. Zakaria ZA, Reezal I, Mat Jais AM, Somchit MN, Sulaiman MR, Marmin $\mathrm{AH}$, et al. The anti-inflammatory, antipyretic and wound healing activities of Cocos nucifera fresh juice and Kernal extract in experimental animals. J Pharmacol Toxicol 2006;1:516-26.

41. Obidoa O, Joshua EP, Nkechi EZ. Phytochemical analysis of Cocos nucifera L. J Pharm Res 2009;1:87-96.

42. Agyare C, Serwaa A, Agyepong DN, Boakye YD, Mensah KB, Ayande PG, et al. Antimicrobial, antioxidant and wound healing properties of Kigelia Africana (Lam) beneth and Strophanthus hispidus Dc. Adv Pharmacol Sci 2013;2013:1-10.

43. Cyric MB, Pai V, Shantaram M, Jose M. Anti-microbial properties of coconut husk aqueous extract on carcinogenic bacteria. Arch Med Res 2013;1:126-30

44. Silalahi J, Permata YM, De Lux Putra E. Antibacterial Activity of hydrolyzed virgin coconut oil. Asian J Pharm Clin Res 2014;7:90-4.

45. Abbas AA, Assikong EB, Martins A, Peter U, Keneth TT. Antibacterial activity of coconut oil and its derivative (Lauric acid) on some selected clinical isolates. Int J Med Sci Clin Invent 2017;4:3173-7. 